Jurnal Medicoeticolegal dan Manajemen Rumah Sakit, 5 (1): 16-24, Januari 2016

Website: http://journal.umy.ac.id/index.php/mrs

DOI: $10.18196 / \mathrm{jmmr} .5102$.

\title{
Kepatuhan 5 Momen Hand Hygiene Pada Petugas di Laboratorium Klinik Cito Yogyakarta
}

Pangisti Dwi Ananingsih ${ }^{1 *}$ \& Elsye Maria Rosa ${ }^{2}$

*Penulis Korespondensi: elsyemariarosa@yahoo.com

${ }^{1}$ Laboratorium Klinik Cito Yogyakarta

${ }^{2}$ Magister Manajemen Rumah Sakit Universitas Muhammadiyah Yogyakarta
Kata kunci:

hand hygiene, kepatuhan, petugas laboratorium

\begin{abstract}
A B S T R A C T
Hospital Associated Infection (HAIs) is still a problem through out the world and in Indonesia. Health officials have a major role in the transmission of these infections. However, the low level of compliance of five moments of hand hygiene among health care workers is still one of the factors that cause high spread of HAIs. To hand let his, it is necessary to counseling about the importance of 5 moments of hand hygiene for health worker towards patient health. Counseling can be done in various models, such as posters, training and simulation. The study is a qualitative research with action research. Conducted in September 2015 in wards in Clinical Laboratory "Cito" Yogyakarta, population as well as samples in this study were all health care workers in first floor of the Clinical Laboratory Cito Yogyakarta that consisting of nurses, analysts, doctors, radiographers, customer service, and cleaning service. 5 moments of hand hygiene compliance of the workers increasing after the poster socialitation, training, and simulation. The management is expected to give more attention in improving of 5 moments of hand hygiene for health worker in Clinical Laboratory Cito Yogyakarta.
\end{abstract}

Hospital Associated Infection (HAIs) masih menjadi permasalahan di seluruh dunia maupun di Indonesia. Petugas kesehatan mempunyai peran besar dalam transmisi infeksi ini. Akan tetapi, rendahnya tingkat kepatuhan hand hygiene di kalangan petugas kesehatan masih menjadi salah satu faktor tingginya penyebaran HAIs. Maka perlu dilakukan penyuluhan mengenai pentingnya 5 momen hand hygiene petugas kesehatan terhadap kesehatan pasien. Penyuluhan dapat dilakukan dengan berbagai model seperti poster, pelatihan maupun simulasi. Jenis penelitian ini adalah penelitian kualitatif dengan action research.Dilakukan pada bulan September 2015 di Laboratorium Klinik Cito Yogyakrta, populasi sekaligus sampel dalam penelitian ini adalah petugas kesehatan lantai 1 Laboratorium Klinik Cito Yogyakarta yang terdiri dari perawat, analis, dokter, radiografer, customer service, dan cleaning service. Kepatuhan 5 momen hand hygiene petugas meningkat setelah dilakukannya sosialisasi poster, pelatihan, dan simulasi. Pihak manajemen diharapkan dapat memberikan perhatian yang lebih dalam peningkatan kepatuhan 5 momen hand hygiene petugas di Laboratorium Klinik Cito Yogyakarta.

(C) 2016 JMMR. All rights reserved

\section{PENDAHULUAN}

Infeksi yang diperoleh dari fasilitas pelayanan kesehatan adalahsalah satu penyebab utama kematian dan peningkatan morbiditas pada pasien. Mengingat asal mula infeksi yang tidak hanyadidapatkan di rumah sakit, istilah infeksi nosokomial diperluas dengan istilah Healthcare-Associated Infections (HAIs). Prevalensi HAIs diperkirakan 1,4 juta di seluruh dunia. Hal ini menyebabkan 50.000 kematian yang disebabkannya dan 2 juta morbiditas disebabkan oleh
HAIs di negara-negara maju setiap tahunnya, serta menghasilkan tambahan 14 hari tinggal di rumah sakit dan tambahan biaya tahunan kesehatan. ${ }^{1}$

WHO mencanangkan programGlobal Patient Safety Challenge "Clean Care is Safer Care" sejak tahun 2005sebagai sebuah komitmen global dalam upaya menurunkan angka HAIs. ${ }^{2}$ Pada tahun 2009 WHO Patient Safety kembali mencanangkan Save Lives: Clean Your Hands sebagai program lanjutan yang bertujuan untuk meningkatkan fokus pelaksanaan hand hygiene pada pelayanan kesehatan di seluruh 
dunia, dimana dicetuskan tentang 5 momen hand hygiene, yaitu melakukan cuci tangan sebelum bersentuhan dengan pasien, sebelum melakukan prosedur bersih dan steril, setelah bersentuhan dengan cairan tubuh pasien, setelah bersentuhan dengan pasien, setelah bersentuhan dengan lingkungan sekitar pasien. ${ }^{3}$

Petugas kesehatan mempunyai peran besar dalam rantaitransmisi infeksi ini.. Akan tetapi kepatuhan hand hygieneseringkali kurangoptimal. Petugas kesehatan seringkali mencuci tangan hanya sebelum dan sesudah menangani pasien saja. Penelitian yang dilakukan pada 40 rumah sakit yang melaporkan bahwa kepatuhan tenaga kesehatan yang melakukan hand hygiene sebelum dan setelah ke pasien bervariasi antara $24 \%$ sampai $89 \%$ (rata-rata $56,6 \%$ ). ${ }^{4}$

Masih rendahnya tingkat kepatuhan hand hygiene di kalangan petugas kesehatan dapat menyebabkan tingginya penyebaran HAIs. Oleh karena itu, perlu dilakukan penyuluhan mengenai pentingnya hand hygiene petugas terhadap kesehatan pasien. Salah satu penyuluhan hand hygiene kepada petugas adalah melalui media cetak poster. Poster merupakan salah satu media cetak yang dapat menyampaikan pesan penyuluhan dalam menyampaikan informasi mengenai hand hygiene. Salah satu edukasi hand hygiene kepada petugas kesehatan selain dengan poster adalah melalui pelatihan. Pelatihan adalah serangkaian aktivitas yang dirancang untuk meningkatkan keahlian, pengetahuan, pengalaman, ataupun perubahan sikap individu. Sedangkan salah satu cara untuk memberikan pelatihan yang berkontinuitas tanpa mengganggu waktu khusus yaitu dengan melakukan pelatihan dengan metode simulasi.

Berdasarkan studi pendahuluan yang dilakukan oleh peneliti di Laboratorium Klinik Cito Yogyakarta yang merupakan tempat penelitian ini, didapatkan hasil dari 5 momen indikasi hand hygienepetugas hanya sering melakukan hand hygiene pada saat setelah kontak dengan pasien saja baru dilaksanakannya hand hygiene, serta langkah-langkah pelaksanaannya tidak sesuai dengan prosedur, dimana tidak ada petugas yang melakukan 6 langkah hand hygienedengan benar. Berdasarkan latar belakang di atas peneliti tertarik untuk melakukan penelitian bagaimana kepatuhan hand hygiene petugas setelah dilakukannya penyuluhan dengan poster, pelatihan, dan simulasi hand hygiene.

\section{METODE PENELITIAN}

Penelitian ini menggunakan metode kualitatif dengan Action Research model Kurt Lewin yang terdiri dari empat komponen yaitu perencanaan (planning), tindakan (acting), pengamatan (observing), dan refleksi (reflecting). ${ }^{17}$ Pada penelitian ini menggunakan tiga siklus, dimana planning dilakukan dengan persiapan pada masing-masing siklus, yang membedakan pada tiap-tiap siklus adalah pada tahap actingdimana pada siklus I dilakukan dengan sosialisasi menggunakan poster, pada siklus II dengan melakukan pelatihan hand hygiene, dan pada siklus III dengan melakukan simulasi hand hygiene, pada tahap observing pada masing-masing siklus dilakukan penilaian dengan checklistkepatuhan 5 momen hand hygiene, dan pada tahap reflecting dilakukan dengan penilaian kepatuhan dan identifikasi masalah faktorfaktor yang mempengaruhi kepatuhan 5 momen hand hygiene pada masing-masing siklus.

Populasi penelitian ini adalah semua petugas diLaboratorium Klinik Cito Yogyakarta yang bertugas di Lantai 1 Laboratorium Klinik Cito Yogyakarta Teknik pengambilan sampel pada penelitian ini adalah dengan cara teknik incidental samplingIncidental Sampling yang digunakan oleh peneliti yaitu petugas kesehatan di Laboratorium Klinik Cito Yogyakarta pada Lantai 1 yang sesuai dengan kriteria inklusi. Kriteria inklusi penelitian ini adalah petugas kesehatan yang ada di Lantai 1 yang berhubungan dengan pasien dan ada pada saat peneliti melakukan observasi, dan kriteria eksklusinya adalah petugas kesehatan yang ada di lantai 1 yang tidak berhubungan langsung dengan pasien (bagian manajemen) dan petugas kesehtan yang tidak ada pada saat peneliti melakukan observasi.

Pengumpulan data dilakukan dengan metode observasi dengan menggunakan checklist kepatuhan 5 momen hand hygienesesuai standar WHO. Penelitian dilakukan pada bulan September 2015, pada masingmasing siklus dilakukan selama 3 hari. Observasi dilaksanakan sebelum dilaksanakannya intervensi dan setelah dilaksanakannya intervensi pada masingmasing siklus. Observasi langsung dilaksanakan hingga mendapatkan 120 momen pada masing-masing siklus. Selain itu juga dengan menggunakan pedoman wawancara mendalam yang dibuat oleh peneliti sendiri untuk mengetahui faktor-faktor yang mempengaruhi kepatuhan 5 momen petugas serta rekomendasi dari 
pihak majanemen untuk meningkatkan kepatuhan 5 momen hand hygiene petugas. Wawancara mendalam dilakukan pada akhir masing-masing setiap siklus.

Teknik analisa data yang digunakan adalah dengan menggunakan analisa deskriptif kualitatif, untuk merefleksikan dari setiap siklus tentang faktorfaktor yang mempengaruhi kepatuhan 5 momen hand hygiene petugas di Laboratorium Klinik Cito Yogyakarta setelah dilakukannya intervensi pada masing-masing siklus dan untuk mengetahui rekomendasi dari pihak manajemen untuk meningkatkan kepatuhan 5 momen hand hygiene petugas. Serta menggunakan analisa deskriptif kuantitatif untuk melihat nilai kepatuhan 5 momen hand hygiene pada saat sebelum dan sesudah intervensi pada masingmasing siklus.

\section{HASIL DAN PEMBAHASAN}

\section{Sebelum Intervensi}

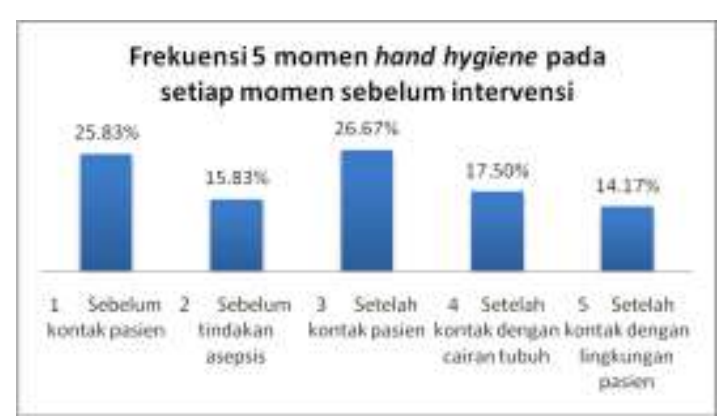

Grafik 1. Frekuensi 5 momen hand hygiene pada setiap momen sebelum intervensi

Momen yang paling banyak terjadi, pada saat sebelum dilakukan intervensi yakni pada momen setelah kontak pasien, sedangkan momen yang paling sedikit terjadi pada momen setelah kontak dengan lingkungan pasien.Sebelum intervensi didapatkan bahwa pada setiap momen tidak ada petugas yang patuh melakukan hand hygiene secara benar sesuai dengan standar WHO.

\section{Siklus I}

Didapatkan hasil momen yang paling banyak terjadi, pada saat siklus I yakni pada momen sebelum kontak pasien, sedangkan momen yang paling sedikit terjadi pada momen sebelum tindakan aseptis.

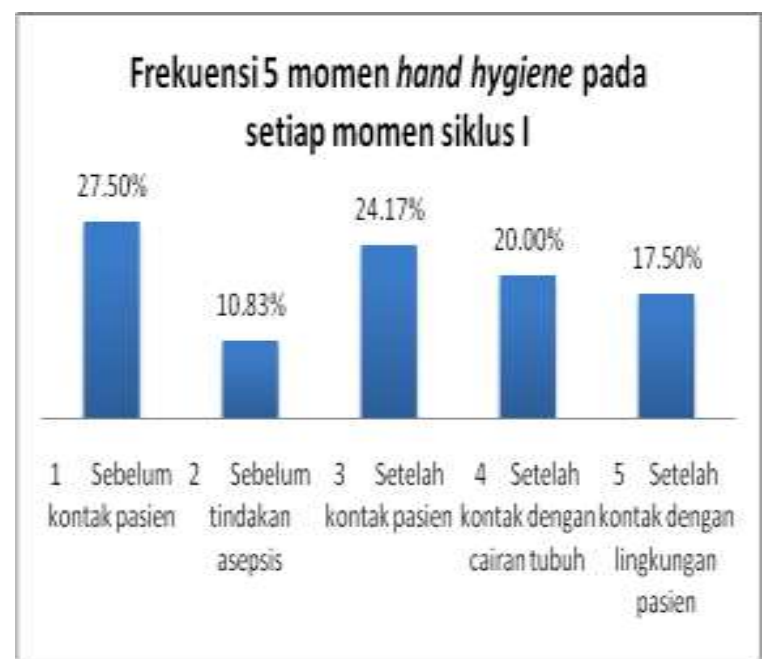

Grafik 2. Frekuensi 5 momen hand hygiene pada setiap momen Siklus I

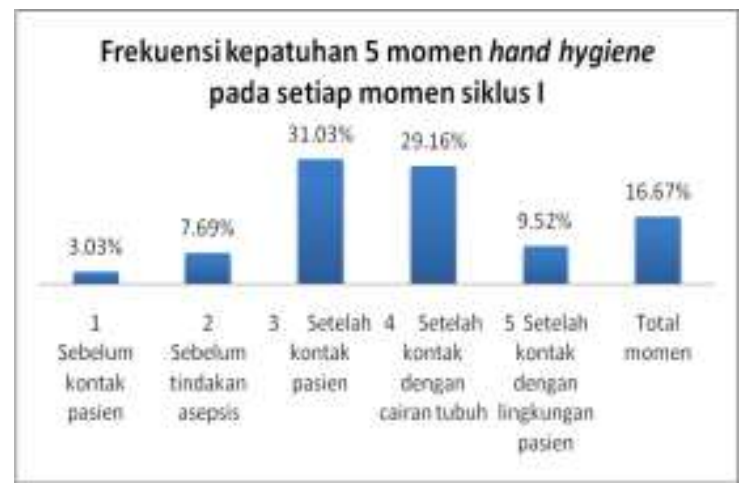

Grafik 3. Frekuensi kepatuhan 5 momenhand hygiene pada setiap momen Siklus I

Kepatuhan paling banyak dilakukan oleh perawat diikuti analis, dokter, radiografer, sedangkan untuk cleaning service dan customer service masih belum ada yang patuh.Berdasarkan hasil wawancara dengan beberapa petugas setelah dilakukannya siklus I, masih rendanya kepatuhan 5 momen hand hygiene disebabkan oleh faktor-faktor seperti : kurangnya pengetahuan tentang pentingnya hand hygiene, kurangnya pengetahuan petugas tentang teknik hand hygiene dan mengenai lima momen hand hygiene, kesibukan yang tinggi, dan akses terhadap fasilitashand hygiene.

\section{Siklus II}

Didapatkan hasil momen yang paling banyak terjadi, pada saat siklus II yakni pada momen setelah kontak pasien, sedangkan momen yang paling sedikit terjadi pada momen sebelum tindakan aseptis. 


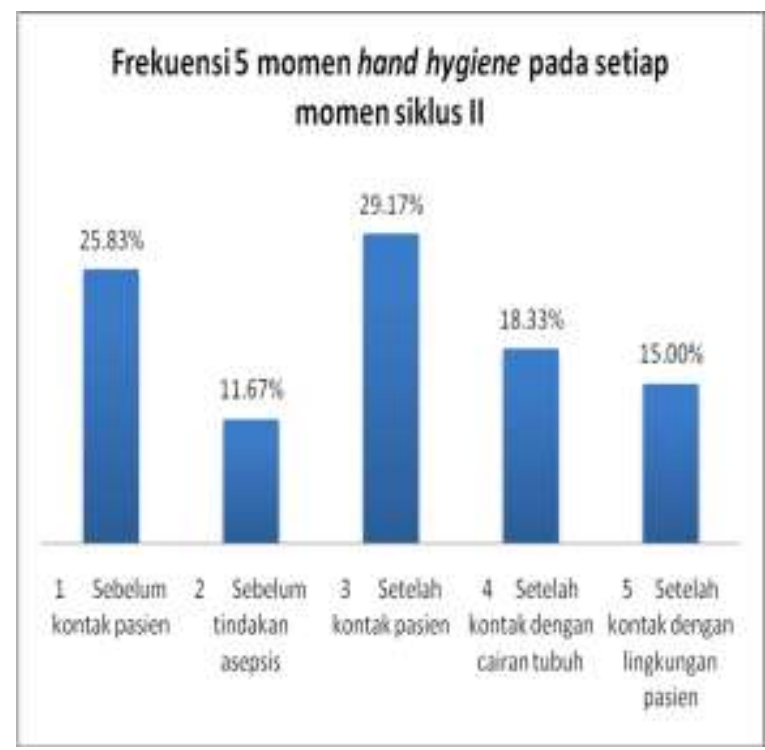

Grafik 5. Frekuensi 5 momen hand hygiene pada setiap momen Siklus II

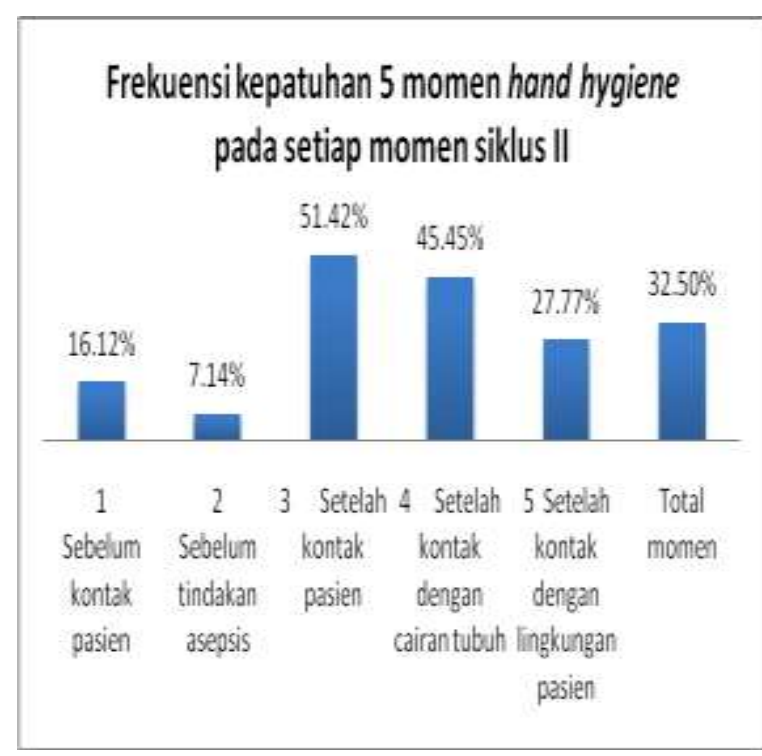

Grafik 6. Frekuensi kepatuhan5 momen hand hygiene pada setiap momen Siklus II

Kepatuhan paling banyak dilakukan pada momen setelah kontak dengan pasien dan paling sedikit dilakukan pada momen sebelum tindakan aseptik. Dari total kepatuhan semua momen mengalami peningkatan yaitu dari $16,67 \%$ pada siklus I menjadi $32,5 \%$ pada siklus II. Kepatuhan paling banyak dilakukan oleh perawat diikuti analis, radiografer, dokter, cleaning service dan customer service.

Berdasarkan hasil wawancara dengan beberapa petugas setelah dilakukannya siklus II, masih rendanya kepatuhan 5 momen hand hygiene disebabkan oleh faktor-faktor seperti : kurangnya pemahaman mengingat petugas tentang teknik hand hygiene dan mengenai lima momen hand hygiene, kesibukan yang tinggi,lupa, dan kurangnya motivasi dari petugas.

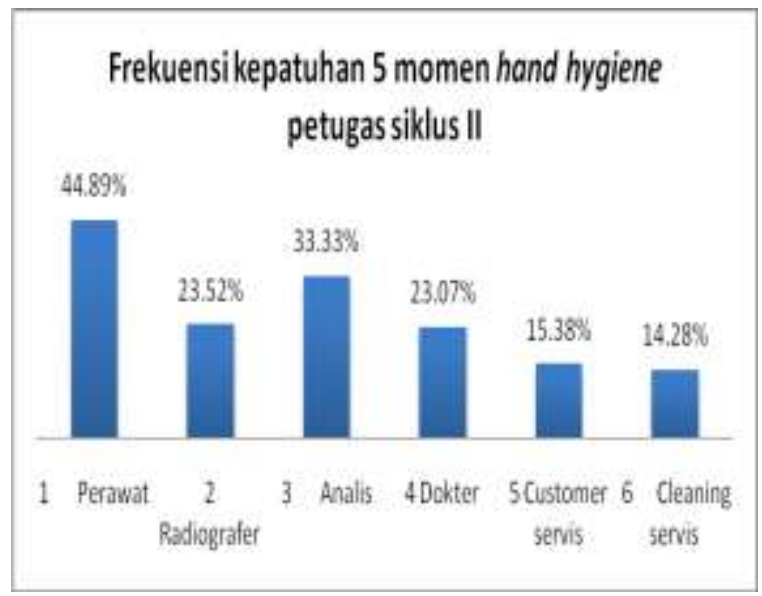

Grafik 7. Frekuensi kepatuhan 5 momenhand hygiene petugas Siklus II

\section{Siklus III}

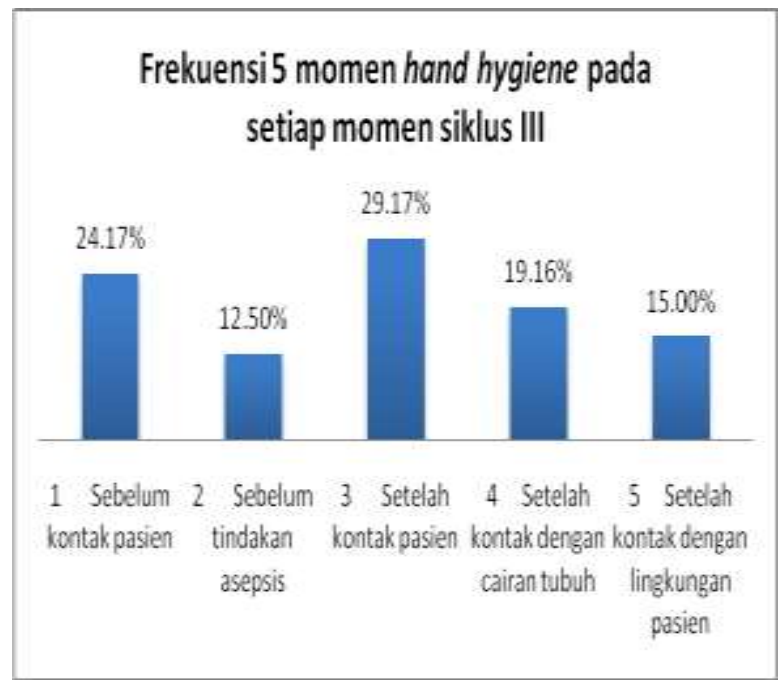

Grafik. 8. Frekuensi 5 momen hand hygiene pada setiap momen Siklus III

Didapatkan hasil momen yang paling banyak terjadi, pada saat siklus III yakni pada momen setelah kontak pasien, sedangkan momen yang paling sedikit terjadi pada momen sebelum tindakan aseptis. Kepatuhan paling banyak dilakukan pada momen setelah kontak dengan pasien dan paling sedikit dilakukan pada momen sebelum tindakan aseptik. Dari total kepatuhan semua momen mengalami peningkatan yaitu dari $32,5 \%$ pada siklus II menjadi $40,83 \%$ pada siklus III.

Kepatuhan paling banyak dilakukan oleh perawat diikuti analis, dokter, radiografer, customer service dancleaning service. Berdasarkan hasil wawancara 
dengan beberapa petugas setelah dilakukannya siklus II, masih rendanya kepatuhan 5 momen hand hygiene disebabkan oleh faktor-faktor seperti : kesibukan yang tinggi, ketakutan terkena dermatitis iritan terkait dengan semakin seringnya terpapar sabun dan airkurangnya motivasi dari petugas itu sendiri kurangnya komitmen perusahaan dalam meningkatkan kepatuhan hand hygiene.

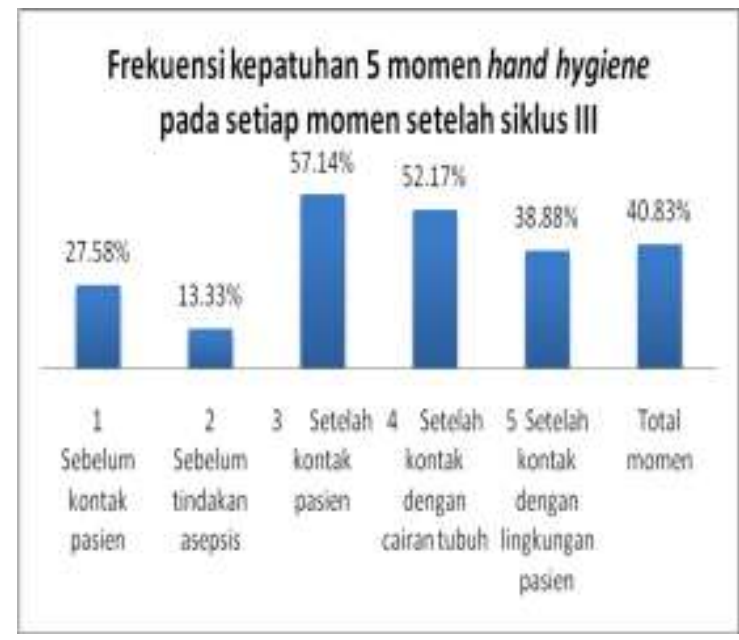

Grafik 9. Frekuensi kepatuhan 5 momen hand hygiene pada setiap momen Siklus III

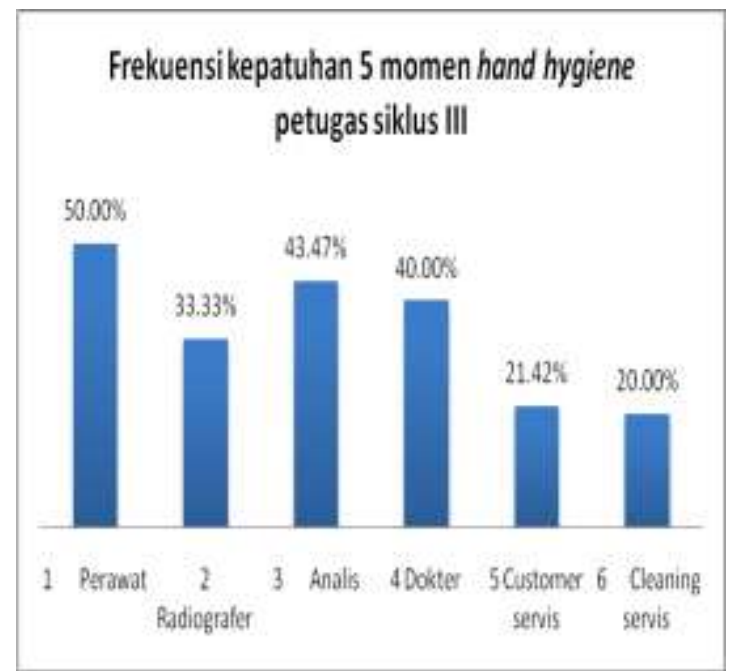

Grafik. 10. Frekuensi kepatuhan5 momen hand hygiene petugas Siklus III

Hasil wawancara rekomendasi kepatuhan 5 momen hand hygiene

Berdasarkan hasil wawancara dengan pihak manajemen, berkaitan dengan masih rendahnya hasil kepatuhan 5 momen hand hygiene petugas, pihak manajemen merekomendasikan akan adanya sosialisai dan observasi mendadak.
Kemudian untuk faktor-faktor yang mempengaruhi kepatuhan 5 hand hygiene mengenai faktor kesibukan pihak manajemen menyatakan dengan cukup menggunakan handscoon jika kesibukan tinggi, pihak manajemen juga menganggap fasilitas hand hygiene yang ada sudah cukup, untuk masalah iritasi dapat diatasi dengan menggunakan sabun rendah iritasi, dari pihak manajemen sendiri juga akan mengadakan pelatihan hand hygiene bertahap, dan memberikan reward bagi petugas yang rajin.

\section{Hasil Uji Analisis Validitas dan Reliabilitas}

Sebelum dilakukan uji hubungan antar variabel, terlebih dahulu dilakukan uji validitas dan reliabilitas instrument kuesioner penelitian. Analisis kesahihan validitas dilakukan dengan bantuan komputer program SPSS 15.00 for windows yang bertujuan untuk mengetahui apakah setiap butir pernyataan dinilai atau dievaluasi dapat dinyatakan valid atau tidak. Simpulan valid tidaknya dari item pertanyaan dilakukan dengan membandingkan koefisien $r_{x y}$ dengan nilai kritis $\left(r_{\text {tabel }}\right)$. Dari hasil analisis ditemukan bahwa nilai $r$ statsitik lebih besar dari pada $r$ tabel. Dengan demikian dapat dikatakan item pertanyaan kuesioner untuk semua variabel valid. Selanjutnya, analisis kesahihan reliablitas dilakukan dengan melihat hasil analisis nilai cronbach alpha. Dari hasil analisis dengan SPSS, ditemukan nilai cronbach alpha lebih dari 05. Dengan demikian, dapat dikatakan bahwa item pertanyaan pada kuesioner untuk semua variabel telah reliabel.

\section{Pembahasan}

\section{Siklus I}

Dari hasil observasi kepatuhan 5 momen hand hygiene petugas di siklus I di dapatkan hasil terjadi peningkatan kepatuhan 5 momen hand hygiene dari $0 \%$ pada sebelum dilakukannya intervensi menjadi $16,67 \%$ pada siklus I. Hal ini sesuai dengan penelitian terdahulu yang dilakukan oleh Higgin dan Hannan dimana terjadi peningkatan kepatuhan 5 momen hand hygiene setelah dilakukannya intervensi dimana poster merupakan salah satunya.

Pengetahuan merupakan salah satu faktor yang mempengaruhi kepatuhan melaksanakan hand hygiene. Tingkat pengetahuan tentang hand hygiene tidak hanya 
sebatas pentingnya pelaksanaannya, namun juga harus mencakup indikasi dan tehnik pelaksanaannya. Hal ini sesuai yang dinyatakan oleh WHO bahwa kurangnya pengetahuan tentang hand hygiene merupakan salah satu hambatan untuk melakukan hand hygiene sesuai rekomendasi ${ }^{7}$. Penelitian lain juga yang mendukung bahwa beberapa faktor yang dapat menghambat petugas kesehatan untuk melakukan hand hygiene adalah faktor ketidakmengertian akan teknik hand hygiene atau standar hand hygiene ${ }^{8}$.

Kesibukan apabila terlalu banyak pasien juga menjadi alasan petugas di Laboratorium Klinik Cito Yogyakarta untuk tidak melaksanakan hand hygienehal itu sesuai dengan Larson dan Killien melaporkan bahwa terlalu sibuk adalah alasan penting yang diberikan petugas kesehatan untuk tidak mencuci tangan mereka. Telah diketahui juga pada jurnal-jurnal terdahulu bahwa salah satu faktor yang mempengaruhi rendahnya pemenuhan hand hygiene salah satunya adalah beban kerja yang tinggi dan kekurangan tenaga9.

Akses terhadap fasilitas hand hygiene juga menjadi salah satu alasan tidak dilakukannya hand hygiene dengan baik.Berdasarkan penelitian Mani, menyatakan bahwa rendahnya akses atau jauhnya menuju fasilitas hand hygiene merupakan satu dari beberapa faktor yang mempengaruhi rendahnya pelaksanaan hand hygiene ${ }^{10}$.

\section{Siklus II}

Dari hasil observasi kepatuhan 5 momen hand hygiene petugas di siklus II di dapatkan hasil terjadi peningkatan kepatuhan 5 momen hand hygiene dari $0 \%$ pada sebelum dilakukannya intervensi menjadi $32,50 \%$ pada siklus II. Hal ini tidak jauh berbeda dari penelitian yang pernah dilakukan oleh Joko Jamaludin, mengenai kepatuhan 5 momen kebersihan tangan pada perawat yang bekerja di unit perawatan intensif Rumah Sakit Pantai Indah Kapuk dengan fasilitas cuci tangan lengkap, dan sebelum penelitian para perawat diberikan edukasi dengan ceramah dan diskusi tentang prosedur kebersihan tangan yang benar. Angka kepatuhan petugas kesehatan meningkat dari 48,14\% sebelum diberi edukasi menjadi $60,74 \%{ }^{11}$.

Kurangnya pemahaman mengingat tentang teknik hand hygiene dan mengenai lima momen hand hygiene, kesibukan yang tinggi serta lupa dikarenakan kesibukan masih menjadi masalah ketidakpatuhan petugas di Laboratorium Klinik Cito Yogyakarta setelah dilakukannya pelatihan.Dua penelitian yang disebutkan dalam jurnal Lau Chun Ling menilai efek kelupaan padakepatuhanhand hygiene. Sekitar 27\% $50,8 \%$ petugas kesehatan mengatakan mereka gagal untuk mengingat bahwa mereka harus melakukan hand hygiene $^{12}$.

Masih kurangnya motivasi dari petugas itu sendiri merupakan salah satu penyebab ketidakpatuhan hand hygiene. Motivasi adalah faktor yang berpengaruh di dalam proses pembelajaran dan salah satu tujuan dari pelatihan adalah untuk meningkatkan motivasi peserta untuk belajar. Pelatihan juga dapat meningkatkan motivasi. Seseorang yang memiliiki motivasi yang tinggi, dapat meningkatkan kinerjanya, hal ini sesuai dengan hasil penelitian yang dilakukan oleh Riyadi yang menemukan adanya hubungan yang signifikan antara kinerja dengan perilaku ${ }^{13}$.

\section{Siklus III}

Dari hasil observasi kepatuhan 5 momen hand hygiene petugas di siklus III di dapatkan hasil terjadi peningkatan kepatuhan 5 momen hand hygiene dari $0 \%$ pada sebelum dilakukannya intervensi menjadi 40,83\% pada siklus III. Hal ini masih lebih baik dibandingkan dengan penelitian yang dilakukan oleh Zulpahiyana dimana menunjukkan hasil bahwa pelaksanaan hand hygiene sebelum intervensi (simulasi hand hygiene pada handover keperawatan) dengan prosentase $39,17 \%$ meningkat menjadi $61,66 \%$ setelah dilakukannya intervensi pada handover keperawatan.

Berdasarkan hasil wawancara, salah satu petugas mengatakan ketakutan akan adanya iritasi apabila melakukan cuci tangan yang sering dan berulang. Dalam beberapa jurnal internasional, diketahui salah satu hal yang menjadi alasan rendahnya pelaksanaan cuci tangan oleh petugas kesehatan adalah iritasi kulit. Seperti halnya dalam jurnal yang ditulis oleh C. Williams dkk, dinyatakan bahwa penyebab dari iritasi seperti sabun, deterjen, air, dan gesekan baik dirumah ataupun dilingkungan kerja ${ }^{14}$. Dalam jurnal yang berbeda, Aisye D. Aikol menuliskan beberapa alasan petugas kesehatan tidak mencuci tangan salah satunya adalah akibat iritasi kulit dan kekeringan $^{15}$. 
Komitmen kelembagaan dalam meningkatkan kepatuhan hand hygiene di Laboratorium Klinik Cito Yogyakarta belum ada, belum adanya regulasi yang tegas menyatakan hand hygiene harus dilaksanakan pada momen yang telah distandarkan serta belum adanya sosialisasi mengenai hand hygiene, bahkan untuk poster mengenai hand hygine pun masih sangat sedikit dan tidak sesuai dengan standar dari WHO.Komitmen kelembagaan sangat penting untuk meningkatkan kepatuhan hand hygiene. Hal ini sesuai dengan hasil penelitian yang dilakukan oleh Khaled, dkk menunjukan adanya prosedur tetap pencegahan infeksi dan dukungan kelembagaan yang diikuti dengan observasi secara terus menerus serta umpan balik kinerja perawat dapat meningkatkan praktik cuci tangan sebesar 97,3\%. Dalam jurnal lain disebutkan bahwapetugas kesehatan mengklaim bahwa salah satu alasan rendahnya tingkat kepatuhan mereka terhadap hand hygiene disebabkan oleh apatis administratif dan rendahnya prioritas institusi terhadap hand hygiene ${ }^{12}$.

\section{Keseluruhan Siklus}

Berdasarkan hasil dari frekuensi 5 momen hand hygiene pada setiap momen yang terjadi pada sebelum intervensi, Siklus I, Siklus II, dan Siklus III didapatkan bahwa frekuensi 5 momen hand hygiene yang terjadi tidak selalu meningkat pada setiap siklusnya, dimana didapatkan ada yang menurun dan ada yang meningkat pada masing-masing momen setiap siklusnya. Demikian juga dengan hasil dari frekuensi kepatuhan hand hygiene pada setiap momen semua siklus, didapatkan pada momen setelah tindakan asepsis juga mengalami penurunan walaupun tidak signifikan pada siklus II (setelah pelatihan), namun kembali meningkat pada siklus III ( setelah simulasi). Hal ini tentunya berhubungan dengan motivasi dari para petugas itu sendiri dalam melaksanakan kepatuhan 5 momen hand hygiene di Laboratorium Klinik Cito Yogyakarta.

Seseorang yang memiliiki motivasi yang tinggi, dapat meningkatkan kinerjanya, hal ini sesuai dengan hasil penelitian yang dilakukan oleh Riyadi yang menemukan adanya hubungan yang signifikan antara kinerja dengan perilaku. Oleh karena itu, diperlukan peran dari pihak manajemen dalam meningkatkan hal ini. Seperti penelitian yang menghasilkan Hawthorne Effect dilakukan disuatu pabrik The Western Electric Company di Cicero, Illinois tahun, 1927-1938. Mereka memisahkan suatu kelompok pekerja untuk diamati. Dimana kesimpulan yang diambil peneliti adalah bahwa produktivitas yang terus naik disebabkan atensi yang diberikan kepada sekelompok pekerja obyek penelitian, bukan karena jumlah penerangan yang diberikan di tempat kerja ${ }^{13}$.

\section{Rekomendasi untuk meningkatkan kepatuhan 5 momen hand hygiene}

Observasi atau pengamatan yang terus menerus dari pihak manajemen juga perlu untuk dilakukan seperti halnya dalam jurnal Lau Chun Ling menyebutkan bahwa dua studi meneliti efek dari kesadaran yang diamati pada kepatuhan hand hygiene dimana ini adalah indikator kuat dari tingginya kepatuhan hand hygiene ${ }^{12}$.

Penggunaan sarung tangan baik bersih ataupun steril tidak mengubah atau menggantikan pelaksanaan hand hygiene. Hand hygiene harus dilakukan sebelum mengenakan sarung tangan dan setelah sarung tangan dilepas (WHO, 2009). Dalam jurnal yang ditulis oleh Ameet Mani dkkdiketahui bahwa salah satu indikasi petugas kesehatan harus melaksanakan hand hygieneadalah saat setelah membuka sarung tangan ${ }^{10}$. Oleh karena itu, dibutuhkan motivasi sendiri dari para petugas kesehatan untuk tetap melaksanakan hand hygiene walau sesibuk apapun. Salah satu cara untuk meningkatkan motivasi adalah dengan pelatihan ${ }^{7}$. Oleh karena itu hendaknya terus dilakukan pelatihan mengenai hand hygiene secara berkesinambungan oleh pihak manajemen.

Rendahnya akses atau jauhnya menuju fasilitas hand hygienemerupakan satu dari beberapa faktor yang mempengaruhi rendahnya pelaksanaan hand hygiene. Berdasarkan dari pengamatan dan data yang ada hanya terdapat satu fasilitas handrub yaitu pada ruang pengambilan sampling. Tentu saja hal ini masih sangat kurang dan menjadikan ketidakpatuhan pada pelaksanaan hand hygiene ${ }^{9,10}$. Oleh karena itu, menurut peneliti pihak menajemen sebaiknya menambah sarana prasarana hand hygiene untuk handsrub dimana sebaiknya disediakan lebih banyak lagi di tempattempat yang strategis.

Penggunaan sabun yang sering dan berulang memang dapat meyebabkan dermatitis iritan, sehingga perawatan tangan yang mencakup penggunaan krim sangat penting untuk mencegah iritasi pada kulit16. 
Dari WHO (2009) juga menyebutkan dalam perawatan kulit terkait dengan hand hygiene menyebutkan bahwa perlunya meyediakan lotion atau krim tangan untuk meminimalisasi terjadinya dermatitis kontak iritan yang disebabkan oleh antiseptik tangan ataupun handwashing.Oleh karena itu, meneurut peneliti pihak manajemen hendaknya tetap menyediakan krim atau lotion tersebut sehingga perawat tidak takut lagi terkena dermatitis yang disebabkan karena mencuci tangan.

Kurangnya komitmen perusahaan dalam hal kepatuhan hand hygiene, dalam jurnal Lau Chun Ling menyatakan bahwa memberikan dorongan atau insentif melalui imbalan bulanan dengan umpan balik kinerja positif juga strategi yang efektif untuk meningkatkan kepatuhan hand hygiene di tingkat administrasi ${ }^{12}$. Oleh karena itu, salah satu cara untuk meningkatkan kepatuhan 5 momen hand hygiene ini adalah dengan memberikan reward bagi petugas yang melaksanakan kepatuhan 5 momen hand hygiene dengan baik dan punishment bagi yang tidak melakukan hand hygiene dengan baik.

\section{SIMPULAN}

Kepatuhan 5 momen hand hygiene petugas kesehatan di Laboratorium Klinik Cito Yogyakarta terus meningkat setelah dilakukan intervensi dengan 3 siklus. Terdapat faktor-faktor yang mempengaruhi kepatuhan 5 momen hand hygiene di Laboratorium Klinik Cito, yaitu kesibukan, ketakutan terkena dermatitis iritan, lupa karena kesibukan, kurangnya motivasi, kurangnya komitmen perusahaan, kurangnya pengetahuan petugas, dan akses terhadap fasilitas hand hygiene.Sehingga diharapkan pihak manajemen diharapkan dapat memberikan perhatian yang lebih dalam peningkatan kepatuhan 5 momen hand hygiene petugas di Laboratorium Klinik Cito Yogyakarta.

\section{DAFTAR PUSTAKA}

1. WHO, 2005. Who Guidelines On Hand Hygiene In Health Care.

2. Whitby, M,dkk. 2007. Behavioural considerations for hand hygiene practices: the basic building blocks. Journal of Hospital Infection.

3. Sax, H, dkk. 2009. The World Health Organization hand hygiene observation method. American Journal of Invection Control.

4. Suryoputri AD, 2011, Perbedaan angka kepatuhan cuci tangan petugas kesehatan di RSUP DR. Kariadi studi di Bangsal Bedah, anak, interna, dan ICU, UNDIP, Semarang.

5. Musdad, Anwar, Lubis A, 1993, Kejadian infeksi nosokomial di rumah sakit di Jakarta, Bul. Penelitian Kesehatan.

6. Shimokura G, Weber D, Miller W, Wurtzel H, Alter M.( 2006). Factors associated with personal protection equipment use and hand hygiene among hemodialysis staff. Am J Infect Control;34:100-7

7. WHO, 2009, WHO guidelines on hand hygiene in health care, First Global Patient Safety Challenge Clean Care is Safe Care.

8. Boyce \& Pitted, 2002, Complience with hand disinfection and it's impact on hospitalacquiredinfection, Journal of Hospital Infection, 48 (Suppl A), S40-S46.

9. Karabay,Ogus,dkk. 2005. Complianceand Efficacy of Hand Rubbing during in Hospital Pratice Diunduh dari : http://web.ebscohost.com

10. Mani, Ameet dkk. 2010. Hand hygiene among health care workers. Diunduh dari : http://web.ebscohost.com

11. Jamaluddin, dkk. 2012. Kepatuhan Cuci Tangan 5 Momen di Unit Perawatan Intensif. Artikel Penelitian Rumah Sakit Pantai Indah Kapuk vol. 2 nomer 3 Juli 2012

12. Lau Chun Ling. 2012. Factors Affecting Hand Hygiene Compliance in Intensive Care Units : A Systematic Review. The University of Hong Kong

13. Riyadi, Slamet. 2008. "Motivasi dan PelimpahanWewenang sebagai variabel Moderating dalam Hubungan Antara Partisipasi Anggarandan Kinerja Manajerial'.Jurnal Riset Akuntansi Indonesia

14. Williams C, dkk. 2009. Adouble-blind, randomized study to assess the effectiveness of different moisturizers in preventing dermatitis induced by hand washing to simulate healthcare use. Diunduh dari : http://web.ebscohost.com 
15. Akyol, Aisye D, 2005. Hand hygiene among nurses in Turkey : opinions and practices. Diunduh dari : http://web.ebscohost.com

16. Keevil, Bill. (2011). Reducing HAIs in ICUs with copper touch surfaces. University of Southampton.

17. Pratomo, H., dan Sudarti. 1986. Pedoman Usulan Penelitian Bidang Kesehatan Masyarakat dan Keluarga Berencana. Jakarta: Depdikbud. 